\title{
Kajian Pendidikan Era Covid-19: Pengaruh Pembelajaran Daring Terhadap Kesehatan Remaja di Masa Pandemi
}

\author{
Aprilia Husna ${ }^{1 *}$, Rama Fadli ${ }^{2}$, Angelina Br Sembiring ${ }^{3}$, Sri Andini ${ }^{4}$, Sakti \\ Ritonga ${ }^{5}$ \\ ${ }^{1}$ Universitas Islam Negeri Sumatera Utara Medan, Indonesia \\ ${ }^{2}$ Universitas Islam Negeri Sumatera Utara Medan, Indonesia \\ ${ }^{3}$ Universitas Islam Negeri Sumatera Utara Medan, Indonesia \\ ${ }^{4}$ Universitas Islam Negeri Sumatera Utara Medan, Indonesia \\ ${ }^{5}$ Universitas Islam Negeri Sumatera Utara Medan, Indonesia \\ * Corresponding Author. E-mail: ${ }^{1}$ apriliahusna@gmail.com
}

Receive: 13/01/2021

Accepted: 23/01/2021

Published: 01/03/2021

\begin{abstract}
Abstrak
Penulisan artikel ini dilatar belakangi adanya beberapa kendala yang dialami remaja ketika pembelajaran daring. Tujuan penulisan ini untuk mengetahui kesehatan mental remaja dalam proses pembelajaran selama pandemi Covid-19. Model penelitian ini merupakan analisis deskriptif kuantitatif menggunakan instrumen penelitian berupa kuesioner yang disebar secara online menggunakan bantuan Google Form. Jumlah sampel pada penelitian ini merupakan 11 siswa Sekolah Menengah Atas (SMA) yang berasal dari berbagai sekolah yang ada di Medan. Hasil penelitian menunjukan bahwa terdapat beberapa kendala didalam pembelajaran daring, diantaranya sering merasa malas karena ngantuk dan bosan, jaringan yang tidak stabil dan juga kurang mengerti pada penjelasan yang diberikan oleh guru. Terkait dengan hal tersebut, 90,9\% dari 11 siswa lebih menyukai sekolah seperti biasa dibandingkan dengan sekolah dari rumah yang dengan persentase hanya $9,1 \%$.
\end{abstract}

Kata Kunci: Pembelajaran Daring, Kesehatan Mental, Remaja.

\section{The Study of Education in the Covid-19 Era: The Effect of Online Learning on Adolescent Health during the Pandemic}

\begin{abstract}
The background of writing this article is that there are several obstacles experienced by teenagers when learning online. The purpose of this paper is to determine the mental health of adolescents in the learning process during the Covid-19 pandemic. This research model is a quantitative descriptive analysis using a research instrument in the form of a questionnaire distributed online using the help of Google Form. The number of samples in this study were 11 high school students (SMA) from various schools in Medan. The results showed that there were several obstacles in online learning, including often feeling lazy because of being sleepy and bored, unstable network and also not understanding the explanation given by the teacher. Related to this, $90.9 \%$ of 11 students prefer school as usual compared to school from home which is only $9.1 \%$.
\end{abstract}


Keywords: Online Learning, Mental Health, Youth.

\section{Pendahuluan}

Dunia saat ini sedang mengalami wabah virus corona. Coronavirus sendiri merupakan keluarga virus yang sangat besar dan juga merupakan penyakit yang menimbulkan banyak gejala, mulai dari yang ringan hingga berat. Setidaknya ada dua jenis virus corona yang diketahui menyebabkan gejala parah. Dewi (2020: 56) mengemukakan Coronavirus disease 2019 (Covid-19) adalah penyakit baru yang tidak ditemukan pada manusia. Tanda dan gejala umum adalah batuk, sesak napas, demam, muntah dan sakit kepala. Virus corona dapat ditularkan dari mana saja, dari hewan ke manusia dan dari orang ke orang. Gejala muncul 21 hari setelah infeksi tetapi dapat menular tanpa tanda-tanda infeksi (Pemko Medan). Penyebaran Covid-19 di suatu negara dapat diminimalisir melalui serangkaian perilaku tertentu, seperti mencuci tangan dan menjaga jarak. Salah satu langkah yang diadopsi oleh banyak negara adalah kebijakan "Stay at Home" Sumaedi, dkk (2020). "Stay at Home" dapat dikategorikan sebagai perilaku yang berhubungan dengan kesehatan. Kondisi ini mengakibatkan seluruh kegiatan pada berbagai bidang menjadi terhalang dan terhambat, salah satunya pada sektor pendidikan.

Terkait dengan dampak penyebaran virus Corona di bidang pendidikan membuat guru dan siswa harus mampu beradaptasi dengan cepat terhadap perubahan yang ada. Sistem yang semula menggunakan sistem pembelajaran tatap muka di kelas kini digantikan dengan sistem pembelajaran virtual (online learning).

Salah satu jenjang pendidikan yang paling terkena imbas penangguhan merupakan jenjang Sekolah Menengah Atas (SMA). Hal ini dikarenakan kaum muda sebagai kelompok yang kurang beruntung sedang melalui masa transisi yang sulit. Pada masa transisi, remaja berada pada tahap mencari identitas diri melalui teman, kelompok sosial, kegiatan keagamaan, atau berbagai kegiatan kelompok lainnya, daripada menggunakan anggota keluarga untuk berkumpul di rumah (Marotz dan Allen, 2013). Interaksi dengan orang-orang dari lingkungan sekitar dapat memberikan kesempatan kepada remaja untuk mencoba berbagai peran hingga menemukan peran yang selaras dengan identitasnya (Miller (2011)). Pemuda dipilih karena menurut teori perkembangan psikososial Erickson, tugas perkembangan remaja saling terkait dan berorientasi pada teman. Pembatasan sosial akibat pandemi Covid-19 meningkatkan risiko stres psikologis yang lebih parah dan berkepanjangan, yang berdampak lebih serius di masa dewasa.

Remaja sekolah rentan terhadap masalah psikososial. Stres psikologis dapat mengubah kehidupan seseorang, memaksa mereka untuk beradaptasi atau mengatasi stres yang muncul. Perubahan gaya belajar adalah salah satu insentif untuk perubahan psikologis, dan kecemasan adalah salah satunya. Kecemasan dapat mempengaruhi hasil belajar remaja karena sering menimbulkan kebingungan dan distorsi persepsi. Kecemasan jangka panjang yang terus-menerus dapat menyebabkan stres dan mengganggu aktivitas sehari-hari. Jika tidak diobati atau diatasi, dapat menyebabkan masalah psikologis yang lebih serius, seperti depresi. Karena pandemi Covid-19 menggunakan metode pembelajaran online, kecemasan, stres, dan depresi kaum muda meningkat.

Selain itu, dalam proses belajar di rumah, banyak faktor stres yang memperparah tekanan psikologis anak dan remaja, antara lain isolasi diri dalam waktu lama, takut tertular, frustasi dan kebosanan, informasi kurang akurat, kurangnya kontak langsung dengan teman dan lingkungan, guru atau interaksi sosial, kurangnya privasi di rumah, masalah keuangan keluarga, dan peningkatan waktu yang dihabiskan di media sosial/internet. Selain itu, kekhawatiran sehari-hari atau gangguan lingkungan sehari-hari juga berperan penting dalam meningkatkan tekanan psikologis remaja, seperti tuntutan akademik, konflik dengan teman, konflik dengan orang tua, kebisingan lingkungan, 
dan sumber daya yang tidak memuaskan. Namun, banyak remaja yang tidak menyadari bahwa hambatan kecil ini akan berdampak negatif pada perkembangan psikologis mereka.

Kita perlu mewaspadai dampak negatif dari penutupan sekolah akibat pandemi Covid-19. Sebagai langkah preventif, pemerintah perlu memahami kondisi psikologis dan kendala yang dihadapi pemuda Indonesia saat melakukan kegiatan sekolah di rumah akibat pandemi Covid-19.

Diharapkan pemerintah serta orangorang sekitar yang dekat dengan remaja agar dapat memberikan tindakan pencegahan dan perawatan yang tepat agar remaja tidak mengalami masalah psikologis yang lebih serius di kemudian hari. Penelitian ini bertujuan untuk menjelaskan keadaan psikologis siswa SMA dan menggali berbagai hambatan yang dihadapi siswa SMA saat belajar di rumah selama pandemi Covid 19 di Indonesia. Penelitian ini harus dilakukan sebagai bentuk upaya untuk mencegah keadaan psikologis remaja agar tidak terjadi efek samping yang serius di kemudian hari.

\section{Metode}

Penelitian ini menggunakan pendekatan penelitian survei yang bersifat deskriptif untuk memberikan gambaran yang lebih rinci tentang situasi atau fenomena. Hasil akhir dari penelitian ini seringkali berkaitan dengan jenis atau pola fenomena yang dibahas oleh Priyono (2016: 21). Responden survei atau penelitian ini adalah siswa Sekolah Menengah Atas (SMA) dari berbagai sekolah di Medan.

Survei dilakukan secara online melalui Google Form. Terdapat sebanyak 11 siswa berpartisipasi dalam penelitian sebagai orang yang telah berpartisipasi menjadi responden penelitian ini. Survei dilakukan pada 18 Agustus 2021. Kriteria partisipasi siswa dalam survei ini adalah siswa Sekolah Menengah Atas (SMA) yang berstatus aktif pada Tahun Akademik 2021 yang sedang mengikuti pembelajaran secara daring.

Pengumpulan data dengan metode angket tertutup. Survei ini terdiri dari sembilan kelompok pertanyaan diantaranya nama, asal sekolah, usia, perasaan yang dirasakan selama pembelajaran daring, pemahaman teori, kendala yang atau hambatan pembelajaraan yang dialami, media online atau aplikasi yang digunakan, pilihan antara sekolah seperti biasa atau sekolah dari rumah, serta alasan memilih pilihan tersebut. Selanjutnya data yang diperoleh menggunakan analisis kuantitatif deskriptif dengan teknik persentase langsung dari Google Form.

\section{Hasil dan Pembahasan}

\section{Hasil}

Berdasarkan survei yang telah dilakukan pada 18 Agustus 2021, diperoleh beberapa data mengenai perasaan yang dirasakan selama pembelajaran daring, pemahaman teori, kendala yang atau hambatan pembelajaraan yang dialami, media online atau aplikasi yang digunakan, pilihan antara sekolah seperti biasa atau sekolah dari rumah, serta alasan memilih pilihan tersebut.

Populasi survei adalah dari seluruh siswa aktif yang menjalani proses pembelajaran yang berjumlah 11 orang. Terdiri dari 6 siswa berusia 15 tahun, 4 siswa berusia 16 tahun dan 1 siswa berusia 17 tahun.

Berdasarkan data kuesioner, diperolah hasil bahwa $81,8 \%$ siswa merasa bosan, $27,3 \%$ merasa sedih, $27,3 \%$ merasa lelah, $27,3 \%$ nyaman, $18,2 \%$ merasa kecewa dan $9,1 \%$ merasa takut.

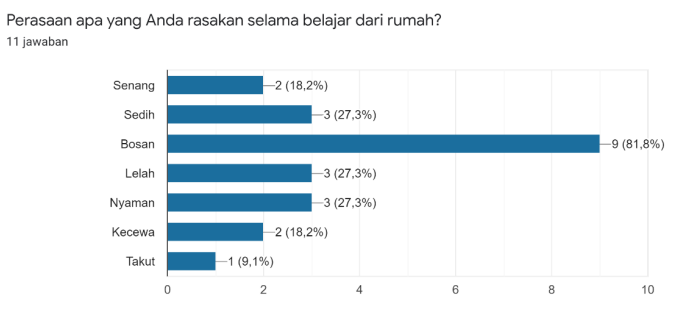




\section{Gambar 1. Perasaan Yang Dialami Oleh Siswa Selama Pembelajaran Daring}

Pada item kuesioner selanjutnya $81,8 \%$ siswa kurang paham terhadap penjelasan materi yang diberikan oleh guru dan 18,2\% tidak paham sama sekali terhadap penjelasan materi yang diberikan oleh guru.

Pada item kuesioner berikutnya memperlihatkan kendala yang dialami siswa dalam pembelajaran daring, seperti jaringan yang tidak stabil, paket data habis, kurang dapat memahami materi, dan bosan belajar sendiri

Terlihat dari isi kuesioner bahwa sarana online yang digunakan untuk pembelajaran online berbeda dan juga beragam. Responden dapat memilih media online mana yang akan digunakan. Google Classroom menduduki peringkat pertama dengan $54,4 \%$, peringkat terbanyak kedua Google Meet 36,4\%, peringkat ketiga Zoom Meeting 27,3\%, peringkat ketempat WhatsApp 18,2\% dan yang terakhir $0 \%$ untuk penggunaan media e-learning.

Pada item kuesioner berikutnya diperoleh informasi bahwa $90,9 \%$ siswa memilih lebih menyukai sekolah seperti biasa/tatap muka dan $9,1 \%$ siswa memilih lebih menyukai sekolah dari rumah (online).

Diantara sekolah seperti biasa dan sekolah dari rumah manakah yang lebih Anda suka? 11 jawaban

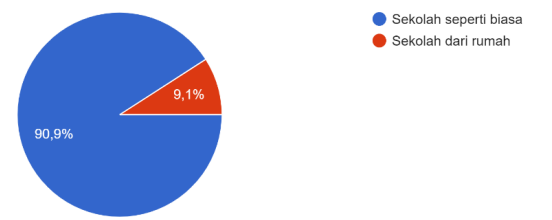

Gambar 2. Tanggapan Mengenai Sekolah Biasa Dan Sekolah Dari Rumah

Mayoritas siswa memilih lebih menyukai sekolah seperti biasa/tatap muka karena terdapat beberapa kendala didalamnya. Siswa mengatakan bahwa lebih menyenangkan jika sekolah tatap muka karena bisa bertemu dan berinteraksi dengan banyak teman, lebih fokus/berkonsentrasi dalam belajar serta lebih mudah untuk memahami materi yang disampaikan.

\section{Pembahasan}

Penelitian dilakukan kepada siswa yang sedang/pernah pembelajaran daring pada tahun akademik 2021 dengan jumlah 11 orang. Hasilnya, semua siswa yang menyelesaikan dan mengisi kuesioner menunjukkan bahwa mereka telah melaksanakan $100 \%$ pembelajaran online mereka pada tahun ajaran 2021. Hal ini menunjukkan bahwa seluruh guru dan siswa telah menerapkan kebijakan pemerintah yang mewajibkan pembelajaran online atau online learning di rumah selama masa pandemi Covid-19.

Informasi yang didapat dari hasil survei adalah pembelajaran online dilakukan melalui berbagai sarana online. Terdapat 3 media online tercantum di atas, Google Classroom 54,4\%, Google Meet 36,4\%, Zoom Meeting 27,3\%, WhatsApp $18,2 \%$ dan yang terakhir $0 \%$ E-Learning. Hal ini memperlihatkan aplikasi yang sangat bervariasi. Media online yang paling banyak digunakan saat pembelajaran online ialah Google Classroom 54,4\%.

Internet telah memungkinkan pembelajaran online, dan banyak pendidik tertarik pada pembelajaran online untuk meningkatkan pembelajaran siswa yang dimana kekurangan sumber daya, fasilitas dan peralatan khususnya di institusi pendidikan tinggi. Pembelajaran online ini menjadi populer karena berpotensi memberikan akses dan bimbingan yang lebih fleksibel kapan saja, di mana saja. Namun, tetap saja terdapat beberapa hambatan didalamnya ketika melaksanakan dalam kegiatan sekolah online, remaja mengalami emosi negatif dan hambatan yang mengganggu aktivitas belajar.

Berlawanan dengan kebutuhan kaum muda atau remaja, stres psikologis dapat mengubah kehidupan seseorang, memaksa mereka untuk beradaptasi atau mengatasi stres yang muncul. Perubahan 
gaya belajar adalah salah satu insentif untuk perubahan psikologis, dan kecemasan adalah salah satunya. Kecemasan dapat mempengaruhi hasil belajar remaja karena sering menimbulkan kebingungan dan distorsi persepsi. Kecemasan jangka panjang yang terus-menerus dapat menyebabkan stres dan mengganggu aktivitas sehari-hari. Jika tidak diatasi, dapat menyebabkan masalah psikologis yang lebih serius, seperti depresi.

Peneliti juga berharap agar pemerintah, orang tua, dan masyarakat sekitar remaja dapat memberikan bantuan psikologis yang tepat dengan fokus pada aspek psikologis lainnya untuk mengurangi dampak negatif pandemi Covid-19 pada remaja.

\section{Simpulan}

Pada akhirnya, sekolah dari rumah atau homeschooling adalah pilihan terbaik negara untuk mencegah penyebaran Covid19 di kalangan anak muda. Namun, remaja mengalami berbagai dampak negatif ketika melakukan kegiatan sekolah di rumah. Penelitian ini bertujuan untuk menggambarkan kondisi psikologis remaja Indonesia pertama yang beraktivitas di rumah akibat pandemi Covid19. Selama homeschooling (belajar sendiri di rumah) remaja kemungkinan besar mengalami empat perasaan, yaitu bosan, lelah, sedih dan nyaman. Namun, dibandingkan dengan emosi positif, remaja lebih cenderung mengalami emosi negatif, yaitu bosan, lelah, sedih, takut, khawatir, dan juga kecewa. Kurangnya sosialisasi dan interaksi dengan orang lain serta kegiatan akademik yang tidak memuaskan adalah alasan utama munculnya emosi negatif. Pemerintah harus memantau dampak negatif dari kegiatan sekolah keluarga untuk mencegah anak muda memiliki masalah psikologis yang lebih serius di masa depan.

\section{Daftar Pustaka}

[1] Dewi, Wahyu Aji Fatma. (2020). Dampak Covid-19 Terhadap Implementasi Pembelajaran Daring di Sekolah Dasar. Edukatif: Jurnal Ilmu Pendidikan, 2(1), 55-61.

https://doi.org/10.31004/edukatif.v2i1.89

[2] Estikasari, Paramita \& Sri Redatin Retno Pudjiati. (2021). Gambaran Psikologis Remaja Selama Sekolah dari Rumah Akibat Pandemi Covid-19. Psikobuletin: Buletin Ilmiah Psikologi, 2(1), 23-36. https://doi.org/10.24014/pib.v2i1.11750

[3] Fakhriyani, Diana Vidya. (2019). Kesehatan Mental. Jawa Timur: Duta Media Publishing.

[4] Miller, P. H. (2011). Theories of Developmental Psychology ( $5^{\text {th }}$ ed). New York: Worth Publishers.

[5] Marotz, L. R. \& Ellen, K. E. (2013). Developmental Profiles: Pre-Birth Through Adolescence ( $7^{\text {th }}$ ed). California: Wadsworth.

[6] Priyono. (2016). Metode Penelitian Kuantitatif. Sidoarjo: Zifatama Publishing.

[7] Sumaedi, Sik, et.al. (2020). Factors Influencing Intention to Follow the "Stay at Home" Policy During the Covid-19 Pandemic. International Journal of Health Governance, 2(1), 13-27. https://doi.org/10.1108/IJHG-05-2020$\underline{0046 .}$. 